\title{
Os minerais são uma fonte de conhecimento e de riquezas: As memórias mineralógicas produzidas por José Bonifácio de Andrada e Silva
}

\author{
Minerals are sources of knowledge \\ and wealth: Field memories by \\ José Bonifácio de Andrada e Silva
}

\author{
Alex Gonçalves Varela \\ Mestre em Geociências na Área de Educação Aplicada às Geociências IGE/Unicamp \\ Maria Margaret Lopes \\ Professora da pós-graduação em educação aplicada às geociências, IGE/Unicamp \\ Doutora em história (USP) \\ Maria Rachel Fróes da Fonseca \\ Pesquisadora do Departamento de Pesquisa da Casa de Oswaldo Cruz/Fiocruz \\ Doutora em história (USP)
}

\begin{abstract}
José Bonifácio de Andrada e Silva tem sua presença marcada na historiografia, de forma quase que consensual, em torno de sua identificação como o "Patriarca da Independência", o que corresponde ao primado concedido ao seu perfil de estadista e parlamentar. Contudo, ele notabilizou-se não apenas como homem público mas também como estudioso e pesquisador do mundo natural. Participou de viagens científicas, foi sócio de sociedades científicas européias, publicou diversas memórias no âmbito da história natural e administrou espaços governamentais portugueses ligados à mineração e à agricultura. Um destes foi a Intendência Geral das Minas e Metais do Reino, e como fruto do seu trabalho neste espaço, foram produzidas memórias científicas no campo da mineralogia. Algumas delas foram publicadas, entretanto outras permaneceram inéditas e dispersas em diversos acervos arquivísticos e bibliográficos. Nosso objetivo é trazer ao público duas dessas dissertações, encontradas no Arquivo do Museu Paulista na Coleção José Bonifácio, relacionadas aos seus trabalhos práticos de mineração no âmbito da Intendência.

PALAVRAS-CHAVE: história das ciências, história das geociências, história do Brasil; história das ciências naturais; José Bonifácio de Andrada e Silva.

José Bonifácio de Andrada e Silva's contribution to History has been considered as remarkable. Mainly identified as the Brazilian Independence articulator and promoter, due to his characteristics as a representative and statesman, José Bonifácio, however, was not only an outstanding politician, but also a researcher in Natural Sciences. He participated in scientific field trips, was a member of European scientific societies, published several Natural History 'memories' and managed Portuguese governmental institutions related to mining and agriculture. One of such institutions was the Kingdom's General Mining and Metals Department. As the result of his activities in this area, he left his 'Memories', an important contribution to the field of mining. Some of them have been published; nevertheless, others are still scattered around different archives. Our main objective is to bring to attention two of his dissertations that are part of Arquivo do Museu Paulista Coleção José Bonifácio and that are related to practical activities in mining while he was at the Mining Department.

KEYWORDS: History of Science, Geo-sciences, Brazilian History, History of Natural Sciences, José Bonifácio de Andrada e Silva.
\end{abstract}


$\mathrm{O}$ propósito de realizar estudos em história das ciências no Brasil encontra em José Bonifácio de Andrada e Silva um campo apropriado e perspectivas fecundas de trabalho. Isso porque, em primeiro lugar, sua presença na bibliografia especializada se faz, de forma quase que consensual, principalmente em torno de sua identificação como o Patriarca da Independência, o que corresponde ao primado concedido ao seu perfil de estadista e parlamentar. São análises portanto que enfatizam o viés político de sua trajetória histórica, deixando de incorporar sua dimensão de naturalista.

No entanto, José Bonifácio notabilizou-se não apenas como homem público mas também como um estudioso e pesquisador do mundo natural. Ele participou de viagens científicas, foi sócio de inúmeras sociedades científicas européias, publicou diversas Memórias no âmbito da história natural e administrou espaços governamentais portugueses ligados diretamente à mineração e à agricultura. Portanto, em que pese a densidade da bibliografia a seu respeito, há lacunas que estimulam a reflexão em novas direções.

José Bonifácio de Andrada e Silva nasceu em Santos em 1763. No ano de 1777, foi para a cidade de São Paulo, onde freqüentou aulas de gramática, retórica e filosofia no ensino preparatório ao ingresso na universidade. Em 1780, viajou para Portugal, matriculando-se em Coimbra nos cursos de direito canônico e filosofia natural. A sua chegada à Portugal coincidiu com o período de abertura às novas idéias em razão das iniciativas do marquês de Pombal. Ali, foi sócio da Academia Real das Ciências de Lisboa. O ingresso na Academia abriria os caminhos de uma brilhante carreira de homem de ciência e lhe traria a glória.

Neste espaço de sociabilidade intelectual e científica, José Bonifácio integrou o subgrupo de naturalistas, que tinha em Domenico Vandelli a figura de liderança e grande destaque. Estes naturalistas esboçaram uma "visão de mundo" que centrava no domínio da natureza - capaz de gerar riquezas, e, portanto, deveria ser cientificamente conhecida e explorada - a alternativa para a recuperação do reino português e do Brasil e a retirada de ambos do isolamento econômico e cultural no qual estavam inseridos.

Como resultado da admiração do duque de Lafões, ganhou uma bolsa de estudos do governo português, como naturalista e metalurgista, para fazer uma viagem científica pela Europa. Durante dez anos freqüentou aulas e academias na Alemanha, Bélgica, Holanda, Itália, Hungria, entre outros países. Na França, por onde começou a viagem, estudou com Antoine François Foucroy e Guillot-Duhamel. Por sua vez, na Alemanha, teve aulas com o geognosta Abraham Gottlob Werner. Participou em várias academias de ciências, como a Academia Real de Estocolmo, Copenhague e Turim, na Sociedade de' Investigadores da Natureza em Berlim, a de História Natural e Filomática em Paris, de Geologia de Londres e de Física e História Natural de Gênova. 
Em 1800 voltou para Portugal, onde foi nomeado professor da Universidade de Coimbra, na cadeira de metalurgia, especialmente criada para ele. Logo a seguir, assumiu o cargo estatal de intendente de Minas e Metais do Reino (carta régia de 18 de maio de 1801), órgão cuja criação deveu-se a uma sugestão sua ao secretário de Estado d. Rodrigo de Souza Coutinho, de quem se tornara amigo e interlocutor. Juntamente com estes cargos estatais, assumiu outros na vida pública portuguesa, como o de membro do Tribunal das Minas, administrador das antigas minas de carvão de Buarcos, diretor do Real Laboratório da Casa da Moeda, entre outros.

A partir deste momento, os estudos científicos tinham que dividir o tempo com os cargos estatais, sobretudo aqueles relativos à esfera administrativa portuguesa. Em outras palavras, o perfil de filósofo e o de homem público passavam a caminhar lado a lado na história de vida do personagem. Não são duas carreiras diferentes ou sucessivas, mas, durante toda a sua vida em Portugal, ele levou simultaneamente uma vida de funcionário do reino e uma vida de homem de ciência. $\mathrm{O}$ seu perfil de filósofo natural e de homem público não podem ser estudados de forma separada, uma vez que se cruzam e entrelaçam, pois esse era o perfil que caracterizava o homem da ilustração. Ele é um típico representante dos laços estreitos que se criaram durante o reformismo ilustrado português mariano e joanino entre os sábios e o governo.

Essa cooptação dos filósofos pelo Estado, sobretudo no final do século XVIII, permite observar a valorização daqueles que detinham o conhecimento científico e técnico, sobretudo para darem o seu parecer sobre os mais variados assuntos econômicos/administrativos. No período da "viradeira", ocorreu uma forte identificação entre ciência e política, ou melhor, entre aqueles que produziam o conhecimento científico e os que eram capazes de arregimentar apoio e recursos financeiros necessários ao desenvolvimento das ciências. Em síntese, isso demonstra o reconhecimento do poder da ciência pelo Estado.

Até então, as "artes mineiras", ou seja, o desenvolvimento, lavra, tratamento e fiscalização das explorações das minas, estiveram sob a alçada do Corpo de Oficiais de Artilharia. Pela primeira vez, um filósofo dedicado à pesquisa e investigação da natureza mineral ocupava o cargo de intendente geral das Minas e Metais do Reino.

Um novo regimento para o funcionamento das minas e estabelecimentos metálicos do reino foi mandado baixar pelo príncipe regente. O alvará de 30 de janeiro de 1802 definiu a competência do intendente geral das Minas e Metais do Reino e a sua respectiva área de atuação. O intendente geral seria o diretor e administrador das Minas e Ferrarias de Portugal, estando a ele subordinadas todas as pessoas e oficiais que nelas prestassem assistência e trabalhassem, assim como todos os indivíduos empregados nas minas e estabelecimentos minerais portugueses, fossem funcionários do rei, fossem de companhias 
particulares de minerações e apurações. O intendente deveria vigiar pela boa economia e lavra regular das minas do reino, assim como cuidar em dar todas as providências necessárias, para que as fundições e fábricas minerais fossem trabalhadas e manipuladas segundo as regras da arte e da ciência metalúrgica.

Esse cargo estatal de intendente das minas era de suma importância, e, por isso, deveria ser ocupado por uma pessoa que tivesse conhecimentos profundos e experiência na área da mineração. Isso porque com a revolução industrial tonava-se imperioso a todos os países saber utilizar melhor os seus recursos mineiros. No século XVIII, a exploração das minas conheceu um auge considerável devido ao crescimento das necessidades ligadas à revolução industrial. Países como a Inglaterra, França, Prússia, incentivavam em grande quantidade o estudo do seu subsolo e a exploração das suas jazidas minerais.

Portugal reconhecendo então a importância do estudo do seu subsolo para a realização de pesquisas na área da mineração, tratou logo de seguir o mesmo caminho dos demais países além-Pireneus, para que então pudesse também promover a sua industrialização. O ministro d. Rodrigo de Souza Coutinho chamou o seu amigo José Bonifácio para dirigir a supracitada intendência, com o fim de que desbravasse o solo português em busca das riquezas do mundo mineral que ali se encontravam depositadas, uma vez que elas eram fontes de riquezas capazes de gerar rendas para a industrialização portuguesa.

Os trabalhos de pesquisa e lavra dos veios de minerais, como o ouro, a prata, o chumbo, o ferro, o carvão, entre outros, ocuparam as páginas de importantes Memórias produzidas pelo filósofo e apresentadas à Academia Real das Ciências de Lisboa. Nelas, José Bonifácio apresentou as suas atividades práticas de mineração nas regiões onde pesquisava. Ele buscou sempre descrever e classificar os minerais encontrados, como também registrar o local onde estavam localizados, uma vez que a prática científica dos mineralogistas do final do século XVIII incorporava a dimensão espacial. Entre estas Memórias, podemos citar a Memória sobre a nova mina de ouro da outra banda do Tejo (1817) e a Memória sobre as pesquisas e lavra dos veios de chumbo de Chacim, Souto, Ventozello, e Villar de Rey na província de Trás-osMontes (1818).

Contudo, algumas destas Memórias permaneceram até os dias de hoje manuscritas e sem saber ao certo sua localização. Edgar Cerqueira de Falcão, em função das comemorações dos duzentos anos de nascimento do Patriarca da Independência, organizou, em 1963, uma coletânea de suas obras políticas e científicas, intitulada Obras científicas, políticas e sociais de José Bonifácio de Andrada e Silva, na qual registrou que alguns dos seus escritos não haviam sido localizados. Para a nossa felicidade, durante as pesquisas realizadas no Museu Paulista, encontramos duas dessas dissertações, as quais, embora tenham sido apresentadas à Academia Real das Ciências de Lisboa, não haviam sido 
As Memórias produzidas pelo ilustrado José Bonifácio de Andrada e Silva foram analisadas na dissertação de mestrado de Alex Gonçalves Varela intitulado Cientista e bomem público: uma análise do pensamento do ilustrado José Bonifácio de Andrada e Silva (1780-1833), que contou com o apoio da Fapesp, e orientação da profa. dra. Maria Margaret Lopes e co-orientação da profa. dra. Maria Rachel Fróes da Fonseca. publicadas, permanecendo inéditas até os dias de hoje, segundo os registros encontrados. As Memórias são:

- Memória minerográfica sobre o distrito metalífero entre os rios Alva e Zezere. s. 1., s. d., Loc.: Museu Paulista doc. 291. (Ainda não conseguimos obter informações quanto ao dia em que esta Memória foi apresentada na Academia).

- Memória minerográfica da serra que decorre de Santa Justa até Santa Comba e suas vizinhanças na provincia do Minho. Localização: Museu Paulista doc. 290. (Esta Memória foi lida perante a Academia entre 1814 e 1815, uma vez que sua referência encontra-se na p. 18 de História e Memórias da Academia Real das Ciências de Lisboa, tomo IV, parte II, Lisboa, 1816.)

A publicação destas duas Memórias nos ajudará a compreender melhor o papel que os estudiosos "portugueses naturais do Brasil" tiveram no projeto reformista ilustrado português que buscava conhecer melhor as potencialidades econômicas da natureza do reino e das suas colônias. Os dirigentes lusos acreditavam que a exploração racional das "produções do mundo natural" poderiam gerar rendas que contribuiriam para fomentar o processo de industrialização de Portugal, tirando assim o reino da crise econômica em que se encontrava no final do século XVIII. O trabalho de mapear e inventariar a natureza colonial e metropolitana contou com a participação de estudiosos das mais diversas partes do seu império ultramarino, como José Bonifácio de Andrada e Silva, o português D'Andrada, como ficou conhecido no mundo científico europeu.

\section{REFERÊNCIAS BIBLIOGRÁFICAS}

Falcão, Edgar

Cerqueira de (org.) 1963

Lopes, Maria Margaret set.-dez. 1990

Munteal Filho, Oswaldo 1998

Sousa, Octavio Tarquínio de 1957
Obras científicas, políticas e sociais de José Bonifácio de Andrada e Silva. Santos, Rev. dos Tribunais.

'José Bonifácio de Andrada e Silva, o mineralogista, na produção historiográfica brasileira'. Quipu, vol. 7, no 3, pp. 335-44

Uma sinfonia para o novo mundo: a Academia Real das Ciências de Lisboa e os caminhos da ilustração luso-brasileira na crise do antigo sistema colonial. Tese de doutoramento, Departamento de História da UFRJ, Rio de Janeiro.

História dos fundadores do império do Brasil: José Bonifácio de Andrada e Silva. Rio de Janeiro, José Olympio, vol. 1. 


\title{
Memória minerográfica sobre o distrito metalífero entre os rios Alva e Zezere.
}

\author{
s. d., s. 1. \\ Loc.: Museu Paulista, doc. 291.
}

A natureza, que em tudo procede sempre debaixo de leis fixas e constantes, seguiuas também na distribuição que fez dos metais em certos espaços, e em certas formações. Têm os mineralogistas mineiros já alcançado e descoberto por assíduas observações, que os metais, seja em bancos e camadas, seja em betas e vieiros, ou em outros jazigos análogos, estão sempre, não solitários, nem dispersos ao acaso, mas sim reunidos e ligados entre si formando grupos e afaciações, que os mineiros chamam depósitos: estes podem ser mais ou menos extensos; mas são todavia sempre circunscritos e distintos. Se estes depósitos são de betas e vieiros, que se acompanham uns aos outros em pequenas distâncias, e se reunem ou cruzam na sua direção ou inclinação, ocupando espaços consideráveis, então formam o que chamam distritos ou comarcas metalíferas, cuja descrição pertence à corografia metálica. O conhecimento exato da natureza, configuração, limites, e outras particularidades atendíveis de semelhantes depósitos e distritos, é de maior interesse não só para os diretores de minas, mas igualmente para os geólogos e naturalistas, que se ocupam no conhecimento e teoria do globo.

Nem um país da Europa é mais rico de semelhantes depósitos que o nosso pequeno Portugal. É incrível, apesar de estar o seu terreno quase inteiramente para examinar e descrever, é incrivel, digo, a imensa riqueza já conhecida, mas ainda desaproveitada, que encerram as entranhas de seus montes, e altas serranias. Há só 14 anos (estes assaz embaraçados e desastrosos) que voltando das minhas longas e dilatadas viagens pela Europa me dei, quanto em mim coube, ao estudo da minerografia portuguesa, e todavia pelo pouco que tenho examinado, e pelo que fiz indagar pelas províncias, e por algumas outras notícias, que recolhi já conheço mal ou bem, acima de cinco depósitos minerais, que prometem ser um dia fontes perenes de riqueza pública e particular. Os minerais úteis de que constam, segundo a ordem da sua maior freqüência e abundância, são os seguintes: ferro, chumbo, antimônio, cobalto, carvão-de-pedra, estanho, zinco, prata, cobre e ouro. É de lastimar que Portugal seja ainda uma Índia européia como lhe chamava o imortal Carlos de Linné, escrevendo ao dr. Domingos Vandelli.

Apesar da falta de saúde, de que sofro habitualmente, e do tempo que me não sobra para o cabal desempenho das muitas e penosas ocupações públicas, tinha empreendido descrever e publicar os tesouros minerais do reino em uma obra intitulada Testamento Metalúrgico, que me propunha deixar em herança à posteridade portuguesa; porém refletindo que esta demora poderia ser taipada de egoísmo, ou pouco caso dos presentes, resolvi-me, por me ser também mais fácil e cômodo nas minhas atuais circunstâncias, a ir sucessivamente publicando em pequenas Memórias a descrição de cada depósito, ou distrito separadamente. Já comecei a ler nesta Academia a do distrito metalífero das 
serras de Santa Justa e Santa Comba e suas vizinhanças na província do Minho, e a da formação aurífera da outra banda, agora continuarei com o distrito de Coja, onde conto poder abrir brevemente minas de chumbo, e depois sucessivamente outras começando pelas do terreno de Pampilhosa, se as últimas pesquisas, que ordenei, corresponderem, como espero, aos meus desejos e esperanças.

As povoações deste distrito metalífero são: de vilas, Arganil, Avô, Tajão, Pampilhosa, e Vila Cova, de lugares, assim grandes como pequenos, Aforria, Cadafar, Castanheira, Cavaleiros, Celariza, Cepos, Coelheira, Colmeal, (?), Folgeses, Fundão, Gandujo, Piodão, Piscanceiro, Cimeiro, e Fundeiro, Pereirinha, Secarias, Sergedo, Leiroco, Relvavelha, e Leipura. A área de todo o distrito é de 8.75 léguas quadrados, sendo o seu maior cumprimento 3 léguas e meia, e a maior largura 2 e meia.

É todo o seu terreno áspero, e estéril em grande parte por ser monstruoso e de serrania altíssima, e penhascosa; é cortado por alguns vales, e por muitas quebradas e barrocas, por onde correm os rios Alva, Ceira e Zezere, e as ribeiras e torrentes que vão alimentar, e desembocar nos ditos rios: divide-se a massa montanhosa em dois jugos, ou ramos principais, que saem do centro da serrania da Estrela, e em outras pequenas transversais. O primeiro jugo principal corre entre o Alva, e o Ceira, e acaba no termo da Vila de Góes. O segundo, que é o mais alto, sai da Estrela no sítio chamado Portela das Pedras Lavradas, e vai tomar o nome de serra de Açor, de cujo pendor, ou encosta setentrional nasce o rio Ceira; depois abaixo do rio da Cebola lança para a esquerda um ramo, que dirigindo-se entre a ribeira de Unhais, e o Zezere, forma no termo da Pampilhosa o monte chamado Cabeça da Urra, e mais abaixo outro que chamam Cabeça do Machio; vem por fim acabar por cima da ponte do Cabril, onde desemboca a ribeira de Unhais no rio Zezere. O jugo principal porém continua o seu caminho entre a ribeira de Unhais e o Zezere, tomando em diversos lugares do seu curso nomes diferentes.

As rochas ordinárias de todas estas montanhas, dentro do distrito que descrevo, são de xisto argiloso primitivo de Werner, ordinariamente cor de cinza, com quartzo branco comum em camadinhas, e minhos, e muitas vezes com pirites sulfúreas disseminadas. O quartzo branco é às vezes ocráceo, corta a estratificação das rochas, formando betas e vieiros de diversas prossanca e grossura, em que depois falaremos. Poucas vezes alterna a rocha xistosa com a horneblendica, que pousa sobre, ou esta coberta pelo xisto argiloso. O granito aparece em alguns sítios da serra de Açor, e nos montes que lhe servem de fralda, e que ficam por cima da Vila d'Avô. Encontram-se também algumas formações aluviais de saibro e cascalho, que formam os leitos, e acompanham as margens dos rios e ribeiros.

Passemos agora a minerografia do distrito, segundo os diversos metais, que aparecem: Ouro

Este metal se lavrou em grande abundância em tempo dos romanos, e talvez no dos cartagineses, nas margens do Alva, como se vê, indo do lugar da cocheira por um ribeiro abaixo até sair ao Alva, onde então aparecem muitas escavações nas margens, e numerosas medas de seipos rodados, que no Zezere chamam Conhos, resíduos de antigas e vastas lavras de desmonte, e lavagem, cuja tradição ainda se conserva viva entre 
aqueles moradores. Caminhando do lugar da Tireira para Vila Cova, observam-se vários socavões, e grandíssimo número de medas de seipos rodados, lavras que ainda hoje o povo atribui aos romanos; os quais não puderam esgotar todo o ouro desta formação, pois em tempo do sr. rei d. José se lavraram de novo aqueles sítios, bem que fossem os serviços do ouro de pouca duração, talvez pela ignorância de quem os fizera, ou pela mudança de álveo, que sofreu o Alva, circundando as catas, e subterrando a genuína formação aurífera, com que se dificultaram os trabalhos e diminuíram os lucros.

Outro lugar do Alva, donde no século passado se tirou ouro, é o que fica entre os lugares de Sergedo e Secarias. Dizem que passaram aqueles trabalhos, pelas desordens que fizeram os gandaeiros, que tiravam ouro sem licença ou que pelo temor de serem presos e punidos abandonaram seus trabalhos. Este sítio, se for lavrado segundo as regras e economia da arte montanística, prosperará; porque o ouro não só aparece ainda hoje nos areais do rio, mas nos tabuleiros de pisara argilosa, que formam suas margens; e o que é digno de notar-se, também se acha ouro de pedreira nas betas guarzosas, e ocráceas, que cortam os bancos argilosos dos montes vizinhos e sobranceiros.

Em Vila Cova ainda hoje gandaiam ouro nas areias do Alva. Na ribeira de Fajão que corre por um medonho vale, onde está situado o pequeno lugar chamado de Cavalheiros, há ouro, que costumam grandaciar alguns miseráveis jornaleiros da Vila de Arganil; e tiram às vezes por dia cem, duzentos, até 1.300 de ouro em pó; e houve ocasião em que acharam folheta de três mil de peso, e outra de $18 \mathrm{mil}$, como me consta. Como este vale profundo vem de pequena distância, e corre entre serras xistosas, é muito de crer que o seu ouro venha destas serras; e que nelas, se forem bem e devidamente pesquisadas, se encontre ouro de matriz. (No mencionado lugar de Valheiros observa-se uma grande galeria subterrânea, com medas de escórias, e gangas ocráceas, e muitos vestígios que indicam ter havido ali grande mineração em tempo dos romanos; é de notar que todo o termo, que fica para o norte do lugar, é muito vitriólico.)

A ribeira de Psicansia corre entre outreiros na direção de oeste para leste; suas margens neste sítio merecem exame, porque se acha às vezes ouro engastado, e diferenciado em pequenos veios, cujas gangas são ou quartzosas ou argilas quartozas e marciais. No lugar de Piscanse fundeiro, termo da Pampilhoza, acham nas camadas derrogadas do xisto argiloso muitas pirites marciais, que têm todos os indícios de serem auríferos: demais em alguns vieiros de quartzo branco, que correm com direção ao norte aparece ouro nativo dessidrílico, e em grãos disseminados.

Junto ao vale chamado do Dieguinho há veios quartzosos, que atravessam a ribeira, com ouro disseminado. Nasce esta ribeira na serra do Forcado, que encadeia para o Norte com os montes da Alforria, de que depois falaremos, e vem precipitado, por uma quebrada, ou barroco, que corta o dito monte.

Do exposto até aqui fica claro que este distrito metalífero promete ser um dia, havendo cabedais e boa vontade, um dos mais perenes mananciais do metal, que mais estimam os homens. 


\section{Cobre e Ferro}

Saindo de Coja para o lugar de Folgues, no vale por onde corre a ribeira, encontra-se semelhante mineral de cobre, principalmente de pirites cúpreas, cujas amostras continuam até o lugar da Teixeira. Merece este lugar uma pesquisa regular, e promete mineração considerável.

Saindo do porto da balça, caminho de leste, se vai a Leiroco, e daí a Cervalhos, que está em um profundo vale, acompanhado de altíssimos montes, que vão entroncar na serra do Açor: neste vale há rico mineral de ferro, que contém às vezes chumbo e cobre, o que indica que aprofundando-se o veio crescerá talvez o chumbo e cobre, ou que por aquelas vizinhanças deve haver vieiros próprios destes metais. $\mathrm{O}$ mineral de ferro encaixado dá perto de $70 \%$. Este mineral pela sua riqueza merece ser aproveitado, e para a fusão não falta cepa por aqueles sítios, e para a mineração madeira de castanho, e algumas outras.

No lugar, (...) de Pereirinha aparecem também amostras de mineral de ferro.

Saindo de Fajão, e indo pelo alto da serra, que divide o bispado de Coimbra do da Guarda, encontram-se vagos e dispersos sobre a rocha xistosa pedaços de mineral de ferro.

\section{Chumbo}

Sobre a Vila de Avô nos montes que vão encadeados até a serra do Açor, aparecem veios com ocres de chumbo, que merecem ser examinados constam estas serras de granito, xisto argilosos, e talvez gnaeisse.

Subindo a serra do Açor, e do sítio chamado Cabeça da Chama, indo para o norte da mata da Margaraça, os bancos contêm ocras de chumbo.

Indo para a Castanheiro no vale chamado da Corça, por onde corre norte, e sul um pequeno ribeiro, há um veio pequeno de galena, com mineral de chumbo branco cristalizado.

Nos ribeiros e suas margens do sítio chamado Porto da Balsa, cujos montes são muito altos, há veios de quartzo com ocras, ou veios de chumbo, de três e mais palmos de grossura.

Nos bancos a oeste aparecem seipos avulsos com óxido de chumbo, e também pequenos veios de galena. Esta formação continua por toda a correnteza dos montes de norte a sul, desde o vale do Garcia até a serra do Açor.

Subindo pelo vale do Garcia até o alto, acha-se a mina de chumbo da Alforria, vulgarmente chamada de coja. Tinha-se aberto esta mina em tempos antigos, mas estava entulhado o socavão; o bispo conde reformador reitor a mandou de novo abrir há já anos. Este veio se dirige de norte a sul. Os trabalhos que nele se fizeram foi, primeiro, aprofundar um poço na altura de quarenta palmos, segundo, no fundo deste poço se abriu uma galeria inclinada, do comprimento de 15 palmos; terceiro, no fim dela se aprofundou o segundo poço de vinte palmos de altura; quarto, no fundo deste se abriu uma galeria muito inclinada do comprimento de sessenta palmos. Em todo campo destas lavras, se encontraram diversas betas, ou vieiros, mais ou menos profinates; uns perpendiculares, outros nadantes, ou pouco inclinados. A ganga ou matriz destes vieiros 
é quartzo, que corre entre xisto argiloso. O chumbo se acha em Sado de galena pela maior parte, muitas vezes cristalizada, porém também com chumbo branco cristalizado, e óxido avermelhado, e amarelado. A galena é rica em chumbo e deu pelo ensaio de 60 $70 \%$, segundo as amostras: não contém prata, senão $68 \mathrm{~g}$ por cem arráteis de chumbo. Esta mina está hoje alagada, porque não tiveram o acordo de dar escoantes às águas, ou por bombas, ou melhor com uma galeria de esgoto. Porém creio que não será difícil esgotar as águas; e dar melhor direção aos trabalhos. Do mineral plúmbeo, depois de sorteado, poderá a galena pura ser fundida em forno de reverberio segundo o método inglês, e o impuro em forno de manga, misturando o mineral pesado com cobre calcário e mineral de ferro, que pode vir das mostras para servirem de precipitantes combinandose com o enxofre, e reduzindo os óxidos de chumbo, evitando-se a volatilização deste.

Saindo do pequeno lugar de Piodão para chão da Egoa, a meia légua de distância há uma bela mina de chumbo, cuja galena dá $80 \%$.

Prosseguindo por estes montes até o pequeno lugar do Gandufo, aparece um delgado veio de chumbo, que corre na direção de Leste Oeste, e cuja galena dá também perto de $80 \%$. Este chumbo contém alguma pouca prata, pois deu 3 out. q. gr. por cento, ou quintal de chumbo.

Voltando de Cervalhos, à Castanheira, indo por um grande souto, e caminhando pela serra do Castanheiro, encontram-se amostras de croido de chumbo, e muitas escórias antigas.

Continuando para o vale das Cabras, cheio de densos matos e despenhadeiros, encontram-se vários veios de chumbo, mas delgados.

Os mesmos indícios de chumbo continuam até Fajão.

No termo da Vila de Pampilhosa e lugar de Piscanceiro fundeiro há uma beta que corre em xisto argiloso, e paralelo com a rocha, a qual tem por ganga quartzo mais ou menos ferruginoso e argila cinzenta, penetrados muitas vezes de óxido de chumbo branco e pardacento. Dentro deste veio ou beta logo à superfície aparecem muitos pedaços e às vezes de grandeza considerável de galena de chumbo, cobertos de cera de chumbo e de ferro. Esta beta tem em vários lugares a superfície um palmo de projiansa, como se vê na margem da ribeira, mas subindo para o monte há poucas braças perde-se ao eu parece. Os rústicos asseveram que quando a ribeira está quase seca de verão aparecem cortando o seu leito vários pequenos veios de galena. No sítio chamado o Covão meio quarto de légua de Piscanceiro parece um pequeno veio de dois terços de polegada de projiansa de galena de chumbo, com camisa aos lados de óxido branco de chumbo. Na margem da ribeira subindo para o monte aparece um veio da grossura de um dedo, e seguindo a sua direção e demonstrando-se a terra superficial, que é a argila cor de cinza quando seca, aparecem vários veios, que se cruzam um veio do norte para o sul, e o outro para leste. Neste primeiro veio descapado e aprofundado por socavão de pesquisa se tiravam pedaços de galena de uma arroba de peso, mas estes pedaços não são contínuos, como já disse, mas dispersos na ganga; porém no dia em que se fez esta freguesia se tiravam de pedaços de galena de chumbo acima de quatro arrobas. Foi preciso desmontar oito palmos de altura para descapar o veio. Continuando-se na 
extração do dito veio se extraiu em outro dia em mineral seguido de chumbo 15 palmos de comprido, oito de alto e quatro de largura; mas aí desapareceu o veio: porém os outros paralelos de argila que continuam com regularidade são todos os indícios de haver muito mineral de chumbo para aqueles sítios e vizinhanças. Adauj, ou três tiros de bala da distância deste veio para a direita subindo da ribeira há lembrança de se ter descoberto outro veio, porém o socavão de pesquisa que então se fez está hoje tapado.

Em Alvaro sobre o Zezere descobriu Manoel da Cruz Santiago uma mina de chumbo cujo xisto ignoro, mas creio que era na serra da Boleteira em um vale, onde há uma galeria antiga hoje entulhada por um açude que se fez na barroca.

Há no termo em circunferência de uma légua muita abundância de cepa, algumas matas de medonhos, sobreiros, e pinheiros: e todo o terreno é muito arado e capaz para nele se semearem e criarem grandes matas. A ribeira que corre junto à mina é pequena, mas pode se inverno mover duas rodas: de verão é muito pobre, porque tomam as suas águas para regar os milhos. Mais abaixo quase um quarto de légua se junta a esta outra ribeira, que chamam dos Braçais, e ambas juntas sendo recolhidas em tanque por meio de um açude podem mover todo o verão duas rodas.

O chumbo fundido pode vir em bestas, ou carros a embarcar no Mondego perto do Laredo, distância de sete léguas; e daí ir embarcando até a Figueira.

Além destes metais, até aqui referidos, há indo do lugar chamado a Venda daSerra, para o vale do craril da Carapinha, na serra da Moita, um viveiro de pirites arsenical cristalizada, que corre entre rocha xistosa. Na cerca do convento dos Antônimos da vila de Coja há bancos de xisto decomposto com imensidade de piritas sulfúreas; e às vezes à flor da terra se encontram pedaços de enxofre nativo. Os montes que cercam a vila contêm muitas águas férreas e sulfúricas.

Ao norte do lugar de Cavalheiros há um veio de cobalto em ganga de quartzo. Todo o terreno é muito vitriólico. Caminhando pelo ribeiro, que nasce do Forcado (termo da Pampilhoza) e vem precipitado por uma quebrada até a Quinta do Bispo, aí aparecem os bancos xistosos, decompostos, e penetrados de vitríolo; e nas rochas das margens do ribeiro aparecem veios de piritas sulfúreas com sal de Glanber.

Junto da Vila de Forjão para os cepos, no sítio chamado Foz da Pontinha, há muitas piritas, que têm todos os sinais de serem auríferas: nestes lugares a rocha xistosa alterna com camadas de quartzo branco.

No profundo vale de Cervalhoso, de que depois falaremos, aparecem algumas palhetas de ouro, que requerem mais pesquisas.

No norte de Piscanceiro cimeiro há um barroco cuja terra lavada e batea mostra ouro em pó.

Há neste distrito metalúrgico de entre Alva e Zezere muitas minas do tempo dos romanos, que merecem novo exame e desentulho, ou podem servir de guia para se pesquisarem os veios antigos ou alguns novos, na sua continuação e acompanhamento ou cruzamento. Os sítios, onde sei que acham, são os seguintes:

1) No limite da Castanheira, em um vale chamado o Fragal, há uma galeria antiga da largura de 12 palmos, por onde se podia entrar somente até o comprimento de 15 palmos porque o mais estava entulhado. 
2) Subindo da alforsia para a serra do Açor, logo no princípio se acha uma galeria antiga de vinte palmos de alto, e dez de largo aberta à picão, que atravessa grande parte da montanha, segundo é tradição por uma légua de comprido. Os povos chamam esta mina o Palácio do Rei Açor e crêem que nela há grandes tesouros. Provavelmente foi mina de chumbo argentífero; pois por toda esta serra se encontram veios de chumbo e de antimônio, que ainda não estão pesquisados.

$3^{\circ}$ Sobre os montes da vila de Fajão, em direção a noroeste, há outra galeria antiga de 15 palmos de alto e quatro de largo, onde se acham restos de chumbo fundido, e litargírio.

No lugar de Cavalheiro há um grande socavão, ou mina antiga com medas de pedregulho, e restos de escórias, e ocras, que mostram ter havido ali grande mineração.

4) Da outra banda do monte do Forcado, termo da Pampilhoza, há duas grandes galerias, ou minas antigas, abertas à picão, dos quais a primeira tem seis palmos de alto; e três quartos de largo na distância desta sessenta papos acha-se a segunda, que tem dez de alto e cinco de largo. Na primeira só se pode agora entrar até trinta palmos; na segunda porém até trezentos; e nesta aparecem restos de um poço de luz, ou clarabóia, que tem seis palmos em quadro. Há tradição no povo, que estas galerias atravessam o monte. A rocha que cortam e penetram é de xisto argiloso; as paredes das galerias ainda mostram sinais do ferro e nelas aparecem alguns fragmentos avulsos de carvão, restos do antigo modo de lavrar as minas com fogo posto como praticavam os romanos. Servem agora estas galerias de caneiros de água que represam os lavradores para regar os seus milhos.

5) Ainda que já fora deste distrito metalífero, porém a pouca distância do Zezere, devo referir que saindo da vila de Oleiros caminho de Proença a nova, no sítio chamado o Alto de Fernão Porco, junto à estrada há um grande poço antigo, e junto a ele grandes montes de entulho chamam a esta mina a Cova da Moura. Na encosta do monte e nas suas fraldas há notícia de se terem achado pedaços de quartzo com folhetas de ouro encravado; e contam que um deste pedaços fora vendido a um ourives pelo preço de 14600 (?).

Quando não tivéssemos achado neste distrito todos os jazigos metálicos, que ficam acima apontados bastavam para fazermos juízo da sua riqueza tantos restos de antiga mineração, quais os mencionados. Estou convencido por estudo e longa experiência que onde aparece uma beta possante, de certo há muitas outras que a acompanham ou cruzam. Igualmente onde houver qualquer mineração cartaginesa ou romana de alguma consideração podemos estar certos que os jazigos são ricos; porque esses povos não podiam lavrar minas com proveito e duração, que não fossem ricas e abundosas, pela ignorância da engenharia subterrânea, montanística, e metalurgia própria; por não terem as máquinas de extração e esgoto, que hoje possuímos, e pela falta da pólvora para trocar e dar fogo às rochas e matrizes, sem o que pouco se cava em cada ano, e se pouco sai muito dispendioso. Acrescentamos que os mineiros de então, escravos ou criminosos forçados, nem sabiam minas porque o não tinham aprendido; nem podiam ter zelo e atividade: acrescentamos de novo que grande parte destas antigas minas podem ser desentulhadas, e lavradas outra vez com muito proveito, porque seus jazigos metálicos 
por via de regra estão intactos desde o nível da galeria de esgoto para baixo; e os poços e galerias, existentes são já outras tantas lavras de socorro, de que podemos deitar mão para a nova lavra.

Seria muito interessante e curioso que se fizesse o quadro topográfico de todas essas escavações antigas, que se acham a cada passo pelo nosso Portugal, a que os rústicos chamam furnas, fojos e covas de mouras encantadas; não só a bem da arqueologia lusitânica; mas principalmente para nos servirem de indícios certos, e de estímulo para novos descobertos, e para nova mineração, tanto proveitosa para nós, que havia sido para esses povos industriosos e ricos. Das que tenho visitado, e das muitas outras de que tenho notícias certas ficam fora de toda a dúvida as noticias históricas, que há cerca das grandes riquezas subterrâneas da Espanha, e principalmente da Galícia, Lusitânia e Turdetânia, de cujas porções reformou o nosso Portugal, nos deixaram Políbio, Strabo, Dioscórides, Plínio, Justino e outros. Por uma longa série de séculos, foi Portugal provavelmente para os fenícios, e é certo, para os cartagineses e romanos, o que hoje é para nós o Brasil, e para os espanhóis, o Peru e México.

Mas para aproveitarmos estes preciosos dons da providência são precisos ciência, zelo e cabedais. E por que não teremos? Virá tempo em que acordaremos da profunda modorra, em que temos jazido. É de esperar que nessa paternidade mais instruída, será também mais ativa e corajosa. Haja energia e boa vontade, e seremos ricos e felizes (mas desgraçadamente chegamos os portugueses à situação dos romanos em tempo de Tito Lívio; pois se nós podemos dizer o mesmo que este historiador diria dos seus: "Ad hoc tempora perventum est, quitbus nec vitia nostra, nec remedia pati popumus"). 


\title{
Memória Minerográfica da Serra que decorre de Santa Justa até Santa Comba e suas vizinhanças na província do Minho
}

\author{
Localização: Museu Paulista, doc. 290.
}

Agora que com a paz tem Portugal melhor aspecto, julgo será agradável à S. Majestade ter algumas notícias da natureza e da situação das novas minas de prata, e outros metais que descobri, e tenho mandado pesquisar na corda de serras de Santa Justa, que fica pegado a Valongo, até a de Santa Iria e Santa Comba, na província do Minho. Principiarei esta pequena memória por dar algumas noções históricas sobre as antigas minas dos romanos, que existem nesses montes, por que elas me servirão de indício, e de estímulo para o descobrimento dos novos veios que mandei pesquisar.

Entre os nossos escritores, P. Carvalho, na sua Corografia portuguesa, diz que em "Valongo estão vestígios de minas antigas com muitos fojos (poços) ainda abertos, de que há tradição tiraram os romanos grande quantidade de ouro e prata, e que condenavam os culpados para trabalhar nelas. Em 1804 indo ao Porto, para pôr em atividade as minas de carvão de pedra da Freguesia de São Pedro da Cova, que tinha mandado descobrir em 1803, guiado por esta notícia do padre Carvalho passei a examinar pela primeira vez as minas, e trabalhos dos romanos. Depois em 1809 , tendo já folheado o importante, e curiosíssimo feito cível de Manoel da Cruz Santiago, administrador geral que foi das minas deste reino em tempo do sr. d. João V, o qual desgraçadamente por intrigas, inveja e ignorância, depois de assumir os grandes cabedais que trouxera da América, só conseguiu pôr por prêmio de seus contínuos trabalhos, e patriotismo, ser perseguido, e até insultado pelo procurador da (ilegivel) embusteiro, e temerário, achei nele premissas para fuez alguém mais circunstanciado dos trabalhos, e pesquisas a que este homem benemérito procedera em 1711 para investigar e desentulhar parte destas vastas escavações. Todas estas notícias, e o resultado dos meus próprios trabalhos, assim como as análises, e ensaios que tenho feito tanto no Laboratório Metalúrgico de Coimbra, como no docimástico da Casa da Moeda em Lisboa, me tem convencido, que nesta área de montes desde Santa Justa, até a Serra do Raio, e de Santa Iria, formara a natureza um dos mais ricos depósitos metálicos que conheço por própria experiência, ou pela lição dos AA.

Para convencer-me das riquezas de alguns destes jazigos metálicos, bastava a simples consideração de que os romanos trabalharam nestas minas por mais de seiscentos anos aturados; qualquer mineiro de profissão pode concluir da extensão das suas escavações, e do seu modo de ganhar a rocha a picão, tacunha, e martelo, sem o risco de brocar e dar fogo, então se ignorava. Os mineiros de alguma instrução clássica sabem que os veios minerais trabalhados pelos cartagineses, e romanos, e hoje abandonados, dão grandes esperanças de nova lavra rendosa; pois que estes povos pela falta de conhecimentos científicos da montanística, hidráulica, e mecânica mineral, e pelos seus maus métodos 
da fusão e apuração, não podiam lavrar com lucro e duração se não jazigos ricos, que apesar da falta de economia de minas, e do emprego de escravos desleixados e grosseiros, lhes pudessem pagar as despesas e dar ainda lucro bastante com que se sustentassem e durassem. Por isso todas as minas antigas romanas, que observei em Saltsburgo, Hungria e Tansilvania, são hoje de novo lavradas, e vão dando proveitos aturados. Demais vão passando os seus trabalhos para o fundo a pouco mais que a galeria principal de esgoto, deixaram intacta toda extensão do veio para baixo, que muitas vezes for duro ou três vezes maior que o espaço que lavraram.

Antes porém que dos veios já descobertos e pesquisados, da natureza de suas gangas, e dos diferentes metais que encerram, será conveniente referir aqui em resumo as pesquisas, e trabalhos de Manoel da Cruz Santiago. Consta judicialmente pela deposição do padre Elias de São José, religioso franciscano, que antes de principiar o Santhiago no desentulho e pesquisas destas minas, o dr. P. recebera dele três amostras de ouro, vinda dali de que uma valia $1600 \mathrm{r}$ : consta igualmente que para ajudarem nestes trabalhos levou depois o Santhiago de Lisboa dois oficiais engenheiros, que ali assistiu por tempo de um ano, Nicolau de Abreu, e Francisco da Fonseca de Carvalho. Como o Santhiago, ou não conhecesse, ou não se propusesse lavrar senão o ouro que encontrara neste veios, por isso só limitou os seus trabalhos ao conhecimento e extração das gangas aurífera, para o que levantou dois engenhos de moer a ganga, e separar o ouro pela lavagem, um em Valongo, e outro em Santa Comba, e principiou outra que não pôde acabar. Chamou a mina velha dos romanos, segundo creio, Nossa Senhora das Neves e Almas, e nisso desentulhou a antiga galeria de esgoto por 195 braças; segundo refere Theotonio Lopes da Cruz, escrivão das mesmas minas, que afirma que por meio deste desentulho se deu ao lado desta com outra galeria, que ainda conservava o pavimento de traves, ao que parecia de carvalhos, e que cinqüenta braças da boca da galeria principal deram com uma clarabóia, ou poço de lua de dez braças de altura, e daí mais adiante outro de sessenta braças, que ambos foram desentulhados. Não contente com a indagação do veio principal dos romanos, a um quarto de légua distante desta primeira mina, deu com outra na mesma correnteza da serra que chamou Santo Antonio e Almas. Sua galeria de esgoto ou terá julgo-lhe era de quatro palmos de largo com altura de um homem; e desentulhando-a no comprimento de trinta braças deram com duas betas principais que se causavam com a direção, uma de leste a oeste, e outra de norte a sul: e desaguando uma clarabóia, ou poço de luz que tenha 18 braças de altura, no solo ou praça do carregadouro dele, achavam várias estátuas antigas; algumas das quais pareciam de barro cozido, que deixaram no mesmo lugar; mas na ausência da Santhiago, um frade fanático, e outros sócios da mesma ralé, as quebraram e destruíram.

Mandou prosseguir o Santhiago no desentulho destas escavações para melhor se descobrirem as betas, mas sendo-lhe muito difícil abandonou, e passou na meia ladeira da serra a limpar outra galeria, que a penetra, lavrada e aberta em rocha a picão que se achava entulhada com muitos pedaços de ganga arrancada. No lado esquerdo desta galeria achou uma cruz muito bem-feita aberta em pedra ao picão, o que indica terem estas minas durado até o tempo do estabelecimento do cristianismo nas Espanhas; ou 
pelo menos que nas perseguições contra os cristãos eram estes condenados àquelas lavras. Ensaiando os pedaços de ganga de entulho tirou ouro, mas não lhe sendo possível desentulhar o resto, mandou o Santhiago romper mais abaixo um poço de pesquisa, e deu felizmente com outra galeria de seis palmos de largo, e altura competente, também coberta de picão. Pelo que nela observou, julgou o Santhiago que esta última galeria atravessava sem dúvida alguma todas as betas, ou veios daquele monte, e lhe pareceu ser esta a galeria de extração, por onde os romanos conduziam todo o mineral ganhado para fora. Nestes diferentes trabalhos preliminares ocupou por dois anos 15 obreiros, gastando 35 mil cruzados, que se inutilizavam pelas perseguições que sofreu, e embaraços que recresceram como sempre tem sucedido em Portugal com tudo que é novo e desusado. Além destas minas antigas, passando a examinar os seus contornos e vizinhanças, foi dar com outras, duas léguas destas para o sul, na meia ladeira da serra ou monte de Santa Iria. Na fralda deste monte mandou o Santhiago desentulhar duas galerias de esgoto antigas que ali desembocam, uma das quais tem trinta braças de comprido, em cujos lados achou estátuas, como as já mencionadas: ao lado direito desta galeria deu com uma escavação em forma de sala redonda, como que tinha sido espalhada de madeira, e nas paredes com estátuas já arruinadas com a água que as inundava. A outra galeria tinha somente vinte braças; e ambas tinham sido abertas a picão. Das matrizes que tirou obteve boa faisqueira de ouro.

Pouco distante desta última galeria, para leste alto do monte descobriu o Santhiago, em espaço de dez braças, mais de mil pequenos veios encaixotados em rocha, da possança de um lado, e distantes uns dos outros dado, de queda vertical, e paralelos, atravessados porém às vezes por outros de igual natureza (Gang-zug, ou Stockwerk dos alemães). Mandando lavrar alguns destes vieiros até duas braças de fundo, achou que tanto a rocha adjacente, como a ganga, continham mais ou menos ouro disseminado.

Na mesma serra, e pouco distante para o poente da primeira galeria mencionada, descobriu uma beta possante de mais de dois palmos, cuja matriz pisada e bateada lhe deu ouro. Aprofundando esta beta por dois braços, e alargando-a para os lados outras tantas, tirou ouro tanto da ganga como da rocha adjacente. Porém confessa que não pagava a despesa; e assim the devia acontecer porque não tinha mineiros hábeis que lhe soubessem trabalhar matrizes quartzosas; e porque ignorava que estas precisavam ser trabalhadas a fogo posto como arrancam os alemães e depois ganhada com cunha d'olho e martelo. Demais todas as gangas eram pisadas a martelo, e não em moinho de pilões, e lavadas à mão em bateias, e não em lavadouros ou bolinetes adequados, donde a farinha mineral apanhada fosse depois bem apurada com pouco custo pela amalgamação: e ainda que depois fez uma moenda movida por água para moer o mineral, todavia este mesmo engenho, o qual seria próprio (sendo bem construído) para amalgamar os minerais auríferos, como se praticado em Saltzburgo, não era porém bom para moer o quartzo, nem para a apuração, porque a água que entrava no aperto da moenda levaria consigo não só a parte dos lapídeos, mas também com eles muito ouro em pó. Apesar porém da imperfeição do seu método, afirma contudo Santiago que o mineral assim moído e apurado fazia muita conta; por isso mandou construir outro engenho semelhante, que 
senão acabou como dito por partir para outros estabelecimentos de minas e fundições, que exigiam a sua presença. Assevera nos (sic) o mesmo Santhiago que no comprimento de mais de três léguas, e na largura de mais de uma neste distrito de Valongo e suas vizinhanças descobrira grande número de betas de ouro, de que fizera ensaios. E com efeito nas pequenas excursões que fiz por alguma parte desta serrania, só de veios (sic) a talho aberto observei mais de 14 pesquisados ou lavrados pelos romanos e outros muitos se observam depois na lavra de Santa Iria e suas vizinhanças. Mas quantos se não irão descobrindo diariamente, quando algumas destas minas se lavrarem de novo com a inteligência que merecem!

Ouso confiadamente afirmar que foi a natureza tão liberal neste distrito montanístico, que além destas minas de ouro investigadas, de prata, chumbo, cobalto, zinco e antimônio, de que tratarei, formou também o depósito de carvão de pedra das minas de Valinhos e Passal, cujas minas apesar da perseguição que tiveram todos os nascentes estabelecimentos montanísticos em 1803 e apesar da ocupação, e posteriores invasões do inimigo, já têm trazido a Portugal proveitos de grande monta. Quando as circunstâncias forem mais favoráveis se poderão também fabricar nela pedra-ume e caparosa (sulfato de alumina e ferro) de que abunda o veio de carvão daquele sítio.

\section{Pesquisas e observações que se fizeram de novo}

Em 1801 pela primeira vez visitei as escavações extensas da grande mineração romana do monte de Santa Justa, o qual encadeia com outros até a Serra do Raio, Santa Iria, Santa Comba, como já disse. A rocha de que se compõe estes montes é, pela maior parte, xisto argiloso, que alterna raras vezes o xisto novacular: em alguns sítios há bancos e massas de ferro argiloso.

O primeiro sítio que visitei foi o chamado da Carrera, quase a um quarto da altura total do monte de Santa Justa: nele desemboca uma antiga galeria de esgoto, que mandei desentulhar em 1809 por 180 braças: corta a rocha, e vai unir-se à beta principal em direção pouco oblíqua e quase perpendicular. Os poços que observei na superfície do monte são os seguintes: 1) um poço de luz ou clarabóia, alguma à esquerda da galeria principal, que vai acabar em uma galeria de travessia; 2) subindo o monte ao longo da beta antiga principal no sítio chamado o Cojo Sagrado, em espaço de dez braças, ficam três poços, porém não em linha direta: este cojo ou poço sagrado tem mais de braças de altura; 3) subindo mais até o sítio chamado o Cojo das Pombas há em pequena circunferência cinco poços verticais, uns redondos, e outros quebrados, porém o poço ou Cojo das Pombas é inclinado com os seus degraus talhados na rocha até certa profundidade; e daí para baixo corre um cavaco em degraus como de torre, à maior profundidade até acabar na beta, que aí está lavrada a talho aberto, desde a superfície por não pequena distância: do fim do caracol sai uma galeria que volta à direita, e vai ter ao Cojo Sagrado; 4) no sítio chamado a Barroca da Viúva que fica quase no cimo do monte há uma grande escavação descoberta, que parece ter procedido do desmoronamento do teto sobre alguma sala subterrânea, que aí houvesse, como se observa nos stock werks de estanho da Saxônia, e em algumas minas antigas da Hungria; 
ou talvez por lavrarem a beta pelo método antigo dos romanos, que Plínio chama ruina montium (Hist. Nat., liv. 3). Neste lugar observei vários veios quartzosos chegados uns aos outros, que talvez pela sua reunião dessem motivo a esta espécie de lavra: cumpre examinar se este quartzo contenha ouro; 5) da Barroca da (sic) corre a beta principal dos romanos através da lombada do monte; e está traballhada a tallho aberto até quase ao sítio chamado o Olho do Corvo. Todla esta encosta estava semeada de montículos de pedaços de matrizes, que deixaram os antigos, depois de escolhido o melhor mineral; 6) caminhando para o Sul e junto à (sic) de Santa Justa observei uma nova lavra a talho aberto no sítio chamado $\mathrm{a}$ Valhada. Em outra beta, que aparece correr paralela à primeira já mencionada junto a ela se vê um stockwerk formado de muitos vieiros de quartzo, que se acompanham, cortam, e ramificam. Este talho aberto não foi tão lavrado e continuado como o primeiro acima mencionado. Pretendo examinar se a matriz da beta e do stockwerk contém ouro, o que ainda não pude fazer; 7) continuando para o sul ao longo da encosta da serra acham-se muitas outras lavras abertas a talho aberto com diversos veios; estas lavras porém se acham pela maior parte entulhadas, e carecem ser limpas e investigadas.

A direção da beta principal dos romanos é quase na hora sexta da bússola dos Mineiros, isto é, de poente a nascente: não está ainda descoberta a sua possança ou grossura; a largura das escavações antigas mostra ser de braças. Dos pedaços que pude recolher, e tenho recebido desta beta principal, se vê que a matriz é quartzosa penetrada de piritas sulfúreas, que provavelmente contêm ouro, com algum jahsertz de Werner. Das matrizes desta beta tirou Santhiago ouro; e não admira, porque tal é a tradição imemorial sobre a natureza deste veio, que aindla hoje na povoação de Valongo, que fica nas fraldas do monte, há umas ruínas antigas que sempre se chamaram o Moinho do Ouro. Para se ver a antiguidade da povoação e cultura deste distrito, direi aqui que no lugar chamado Lameiro, ao nascente do Valongo, abrindo-se um poço, só deu-se com uma escavação, onde se acharam várias ânforas, vasos de barro, e outras antiqualhas romanas.

Estas foram as minhas primeiras observações. Sendo porém em 1809 me achei outra vez no Porto, depois de entrada a cidade pelo exército português, e inglês, em que eu também servia como tenente-coronel do Corpo Militar Acadêmico, mandei desentulhar a galeria velha do esgoto dos romanos, que é aberta a picão em rocha inteira, e forma um ângulo quase reto com a beta principal já descrita. Desentulhou-se por 180 braças, até se dar em uma ruína com pedras desmoronadas e caídas que formavam um lado d'água, que impediram continuar o desentulho. Desceram os mineiros as escadas fixas nos lados da escavação da beta até 28 braças de fundo, porém não havendo lados firmes para fixar mais escadas, não foi possível descer até o solo da lavra. Entrando pela boca desta galeria a quase trinta braças acha-se um poço de luz, ou clarabóia, que tem de altura quase 28 braças: a 154 braças (sic) desta mesma galeria (sic) outra de travessia para leste, que foram começadas, mas parece que acabam em mui pouca distância. Como não se podia chegar pela galeria de esgoto atravessar a beta, e penetrar na lavra antiga, começou-se uma galeria nova de rodeio para o lado de leste a 
dez braças de distância da (sic) ou lago, que se lavrou por algumas braças. A beta neste lugar alça-se até a superfície do terreno.

Ao norte da beta principal em que trabalhavam os romanos, descobriu-se um novo veio, que fica distante da galeria pouco mais de cem braças. Este veio foi seguido com diversas pesquisas desde a borda do regato, que recebe as águas da galeria de esgoto, até onde se julgou dever cortar em ângulo oblíquo a beta principal. Corre esta beta noroeste sudeste, e tem de queda $60^{\circ}-70^{\circ}$ para o sul. Examinou-se este veio com um socavão, e três galerias de pesquisa para se poder atravessar. Sobre a prolongação suspeitada deste veio até cortar a beta principal dos romanos, foram encontradas outras pesquisas de socavão; assim como sobre a direção e vizinhanças da beta principal; e começou-se a projetar uma um poço perpendicular em uma nova galeria, que começou a abrir, e de onde se deu uma camada quase horizontal de mina rica de ferro. Do lado do leste e ao sul da beta principal ( falha do manuscrito ) alguns fojos ou poços velhos, que talvez fossem profundados em algumas galerias de travessia e comunicações. Este veio não traz piritas e quartzo, como a beta principal.

Ao sul da beta principal e junto a ela perto do Tojo das Pombas se abriu uma galeria do outro lado da beta, e se deu com algum mineral, que se deve continuar a seguir e profundar este veio já em 1812. Tỉnha de grossura na pequena profundidade a que se tinha então entregado, 14 polegadas de possança; e havia um contrapelo ou estreitamente causado por um banco de mineral de ferro muito rico; é de crer que sejam dois veios diferentes.

Acima da igreja nova de Valongo, no monte de Santa Justa deu-se a pesquisa em um riquíssimo veio de antimônio, que corre quase vertical à beta dos romanos, e fica quase a setecentas braças ao poente da boca de esgoto velho. Este veio pode dar antimônio para toda a Europa.

(falha do manuscrito) ela no ribeiro que corre pelo pé da povoação do Valongo e vai reunir-se ao ribeirão de Ponte Serra é este o ponto mais baixo do monte de Santa Justa. Ali se descobriu uma antiga galeria, que mandei limpar até chegar aos entulhos antigos (Altermann, homem velho dos mineiros alemães). Fora desta galeria um poço velho, que se desentulhou por quatro braças de fundo, ainda bem conservado e inteiro, que finda em uma galeria de travessia, que vai em distância de braça e meio ter ao veio; porém as muitas águas, que vinham filtradas do ribeiro, não se podem esgotar em uma máquina hidráulica; por isso mandei suspender este trabalho. Das pesquisas feitas concluí que os antigos tinham lavrado o veio, que é mui possante, em nível inferior ao leito do ribeiro, e através dele, para o ocidente, e ao que parece seis braças de fundo da superfície do terreno. Logo que for possível convirá da galeria de esgoto aprofundar um poço que vai ter abaixo do solo dos trabalhos antigos para atacar o veio novo e inteiro. $O$ veio de cinco (sic) é possante 13 polegadas e tem como ramos dois vieiros que a superfície estando ainda a estéreis. Mandei fazer outras pesquisas na Freguesia de Alfena onde apareciam alguns veios à superfície, um que fica da aprte de leste foi começado a pesquisar. As outras que vieram são de piritas arsenical, e (incompleto).

No sítio do sobrado, onde também se fez uma pequena pesquisa, aparece um veio, que traz muita blenda negra em ganga quartzosa. 
Em o monte de (falha do manuscrito) um veio de antimônio.

À superfície do terreno apareceu um veio de carvão de pedra de dois palmos de possança, que não profundara, nem se estende em direção.

Ao pé de Vilarinho que fica entre Valongo e Valas no caminho para a Ponte Carr. Onde parece que os antigos fizeram algumas pesquisas, que se achou uma galeria superficial na encosta do monte aberta em um veio que vem à superfície. A rocha de que se compõe este monte é xisto argiloso cinzento (sic). Para se alcançar maior conhecimento do veio começou-se outra nova galeria mais profunda, que na sua prolongação adquirira a altura de quarenta braças. As amostras que me têm vindo sucessivamente de várias pesquisas ao longo do veio animaram-me a mandar contidas com maior atividade na lavra desta galeria; e creio ter descoberto uma mina assaz rica em prata, como depois mostrarei.

Este veio corre noroeste sudoeste, isto é na hora $116 / 8$ da bússola do mineiro, a sua queda geral é de $40^{\circ}$ para poente pouco mais ou menos. A sua possança ou grossura é de um palmo, que às vezes estreita em alguns sítios do seu campus ou extensão até quatro polegadas; e é de notar que quando é mais presente é mais rico o veio de galena de chumbo, e quando menos, de blenda parda denegrida. Em uma das pesquisas na encosta superior do monte, onde o veio constava de piritas sulfúricas quase puras, ou aumentou a possança ou grossura a quase três palmos. A proporção que se ia profundando o veio neste sítio a pirita sufurosa mostrava manchas de blenda parda de negrida e ganga de quartzo se fez em abundância. Desta e das outras pesquisas já feitas se observou que, à proporção que se foi aprofundando o veio, foram também aparecendo mais e mais partículas manchas de galena de chumbo escamosa, de modo que mais para o fundo há toda a probabilidade que predomina a galena e diminua muito e muito a pirita, e a blenda; e é também provável que em vez destas apareçam minerais de prata. Esta beta é das compactas de Werner, e em alguns sítios apresenta uma estrutura em três faixas ou zonas mais ou menos distintas, a primeira ao lado da camisa ou salbanda abunda de piritas quase contínua e pura; a segunda do meio de piritas disseminada em partículas finas de outras partículas de piritas arsenical em ganga quartzosa; a terceira faixa da outra salbanda é de galena em partes separadas escamosas, pura ou mesclada com blenda parda, a qual muito predomina; o veio se estreita como já disse.

Entre a galena há pequenas drusas ou cavidades revestidas de chumbo branco cristalizado. Houve porém lugares em que o veio constava quase inteiramente de galena por mais de braça e meia de comprimento. A galeria que se começou no nível das margens do ribeiro já tem 37 braças de comprido. A seis braças mais distantes da boca desta galeria, e duas mais acima se começou outra na mesma direção do veio, que pode servir de ventilação da primeira, podendo-se ambas comunicar por poços pequenos interiores, desta galeria até o primeiro socavão de pesquisa que se fez no alto do monte distante 550 braças, vai uma altura de 35 braças. $\mathrm{O}$ veio parece continuar na mesma direção por perto de uma légua segundo os sinais na superfície à mil braças da boca da primeira galeria já se fez no seu andamento outra pesquisa, que mostra a sua continuação 
não interrompida. Destes trabalhos haja mais de duzentos carros tirados de minerais de diversas qualidades.

No fim do ano de 1812 mandei examinar as antigas escavações de Santa Comba e suas vizinhanças, que ficam nas fraldas da serra do Raio, que se divide a leste da de Santa Justa pelo norte de Ponte Cerr. ${ }^{a}$, e da de Santa Iria ao sul pelo rio de Aguiar de Sousa.

Os antigos minaram e lavraram em um sítio que fica ao norte da povoação, e ao sul no outro chamado o Braçal, onde há uma bela galeria, que está perfeita, e foi observada por 15 braças da sua boca para dentro, e ainda nela se distingue bem o lugar em que havia uma porta de fechar que fez o Santhiago - mais para dentro há sobre ele um poço de luz ou clarabóia. Parece sem dúvida que esta fosse a galeria antiga que desentulhou o Santhiago. Esta galeria está pouco distante do ribeiro de Ponte Cerr. ${ }^{a}$

O veio se estende muito longe pela montanha dentro, e atravessa uma quebrada até o sítio chamada Casa da Cova, onde há uma como câmara cavada na rocha - consta este veio de piritas sulfúreas e quartzo. Junto a este ribeirão se pode construir uma máquina hidráulica para desaguar as escavações, e lavras antigas dos romanos, que parece eram em três veios, e tinham quatro poços de luz e extração.

Nas vizinhanças da Capela de Santa Comba aparece à superfície um veio possante que atravessa o caminho, e consta de grafite já penetrada de quartzo cinzento de cor e manchas como daquele de cobre. Distante quase duzentas braças da capela passa o ribeiro já mencionado, e em uma de suas margens estava assentado o engenho de moer a pedra e apurar o ouro, que fez o Santhiago, como acima mencionamos. Consta que as gangas e minerais moídos eram tirados das antigas minas da Serra de Santa Iria. No sítio da moenda ainda aprecem restos da Eira (Halde dos Alemães) em que se escolhia e separava o mineral; e dos seus restos me enviavam três amostras, uma das quais é de mineral de ferro argiloso vermelho com quartzo disseminado; outra de uma pedra xistosa alvadiça com marchas de quartzo e ferro argiloso denegrido e algumas partículas de schorl; a terceira leva de xisto argiloso com quartzo ferruginoso. $A$ amostra $n^{\circ} 2$ deu ouro sendo morda a pedra e bateada.

Ao sul da aldeia de Cortumil para o sul na distância quase de duzentas braças fica um monte que mostra ter sido minado e cavado no lado meridional, porém está ainda inteiro no setentrional. Em uma das fraldas deste pequeno monte achou-se uma boca de galeria antiga, que provavelmente servia para a extração do mineral e para o esgoto das águas; mas não aparece em todo o monte fojo ou poço algum antigo. Esta galeria foi desentulhada em 1810 pelo espaço de seis braças, mas o seu desentulho final ficou reservado para melhor tempo. No lado do norte do monte aparecem bancos quase horizontais e muito possantes de mineral de ferro argiloso muito rico, que se estendem por grande espaço. Estes bancos são de muito fácil lavra; e o seu mineral é parte rijo e denso, e parte esponjoso e mole. A rocha interior de que se compõe este monte é de xisto argiloso. No alto do monte aparece uma rocha que tem semelhança com xisto micáceo de grão fino, e é composta de grãos de quartzo e partículas de mica, que altera a sua cor para roxo por causa de partículas de mineral de ferro mesclado, que às vezes 
forma caudas e camadinhas de dentro da rocha. Há outro banco de rochas com aspecto de granito decomposto que consta de ferro argiloso, quartzo e mica amarelada. Estas rochas fazendo-se mais e mais ferruginosas; formam bancos possantes de mineral de ferro argiloso ou mole que parecem dividir-se em cinco camadlas diferentes, e tem todos juntos uma grossura muito considerável.

Além destes bancos de ferro aparece também neste monte um possante veio de cobalto negro terroso denso com piritas sulfúreas disseminadas, óxido esverdeado de Nickel, com ganga de quartzo comum branco. Este mineral além de muito rico em cobalto contém também prata em tal quantidade, que parece ser aproveitada com a que se acha nos centros minerais e argentíferos, descobertos no monte de Santa Justa e suas vizinhanças, de qual já fiz menção.

Na parte do este deste distrito há muita torga e cepa, sobreiros, castanheiros, e pinheiros, e muitos maninhos para novas plantações. Há nele um ribeiro que vem de Ponte Ferr. ${ }^{a}$, que recebe em si o que vem das minas de carvão de São Pedro da Cova. Este ribeirão vai desembocar em pequena distância no rio Louza em águas de Louza, distante das minas de carvão duas léguas. Além destes perto da Aldeia de Cartumil corre outro ribeiro perene, que faz moer de verão três moinhos. Do exposto se vê neste distrito se pode muito bem estabelecer uma fábrica de ferro: porém talvez seja melhor aproveitar também o rico banco de ferro argiloso descoberto na Serra de Santa Justa, que esta fábrica se estabeleça na Freguesia de São Gemil um quarto de légua de Valongo, onde ainda hoje se conserva a antiga levada d' água com o seu açude, de que hoje se servem os camponeses para a rega de seu campos. São Gemil acha-se no meio de cinco freguesias. Que são Cortumil, Santa Comba, Cobelo, Alfema, e São Julião, nas quais há bosques e lenhas suficientes, que só precisam para seu aumento e conservação de bons regulamentos nos cortes, e de novas plantações. Esta casa de fundição custará até oito mil cruzados, e não faltam obreiros pelas aldeias vizinhas.

Além de bancos de ferro do monte de Cortanil, há para aproveitar muita gusa ou ferro cru radioso e celuloso fino, que é já útil ao martelo, e muita mina já fundida antigamente que parece em fornilhos de lupa, de que usavam os romanos, muito pequenos e baixos, como observei em um que foi desentulhado junto às ferrarias da Foz d'Alge em 1803, senão me engano. Na banda desta gusa, e do mineral fundido, que com eles estão calçados os caminhos e feitas paredes internas das casas daquela aldeia: destes pedaços alguns há que pesam duas, três e quatro arrobas. Em pouco tempo se poderá recolher centenares de carradas.

(documento incompleto) 